\title{
Evaluation of the Quality Characteristics of Siirt Herby Cheese: A Traditional Turkish Variety
}

\section{Mubin KOYUNCU ${ }^{1 *}$, Yusuf TUNÇTÜRK ${ }^{2}$}

\begin{abstract}
Herby cheese produced in the Province of Siirt is one of the Turkish cheese varieties. The special parameters applied during the production stages give Siirt Herby cheese unique taste properties. The proteolytic, lipolytic, and electrophoretic parameters of Siirt Herby cheese samples were evaluated. The mean values of water-soluble nitrogen, trichloroacetic acid-soluble nitrogen, and phosphotungstic acid-soluble nitrogen of Siirt Herby cheese samples were $9.49 \pm 2.66 \%, 6.33 \pm 2.39 \%$, and $1.48 \pm 0.71 \%$, respectively. The mean values of free amino group and lipolysis levels were established as $61.97 \pm 30.84$ $\mathrm{mM}$ glycine, and 6.00 $\pm 2.32 \mathrm{ADV}$, respectively. The electrophoretic analysis showed that sheep milk was more preferable for Siirt Herby cheese production.
\end{abstract}

Keywords: Herby cheese, proteolysis, lipolysis, electrophoresis

${ }^{1}$ Mubin KOYUNCU (Orcid ID: 0000-0003-1798-8943) Iğdır University, Research Center for Redox Applications in Foods, Iğdır, Turkey

${ }^{2}$ Yusuf TUNÇTÜRK (Orcid ID: 0000-0001-5240-200X) Yüzüncü Y1l University, Faculty of Engineering, Department of Food Engineering, Van, Turkey

*Corresponding Author: Mubin KOYUNCU, e-mail: mubin.koyuncu@igdir.edu.tr 


\section{INTRODUCTION}

Traditional food products occupy an important place among our consumption habits. These products prepared by traditional methods in rural areas are more widely accepted by consumers compared to industrial products because they were observed as natural products produced faithfully to its origins.

Turkey possesses a wide variety of local cheeses. A lot of varieties of cheese are produced in quite narrow regions (Tarakci and Temiz, 2009). Herby cheese is one of the most preferred types of these types of cheese.

Herby cheese produced by the addition of some herbs grown in the Eastern and South-eastern Anatolia regions is the most widely produced cheese variety in these regions (Coşkun and Tunçtürk, 2000; Tekinşen, 2004; Ocak et al., 2015; Tunçtürk and Özgökçe, 2015; Tunçtürk et al., 2017). Herby cheese that has been in production for more than 200 years is called "Van Herby cheese" since it is produced more in the Province of Van. Van Herby cheese is one of the oldest traditional Turkish cheeses and has been designated of protected geographical indication (PGI) by Turkish Patent and Trademark Office (PDO) (C2017/070). In fact, Herby cheese is produced predominantly in Van as well as the Provinces of Diyarbakir, Siirt, Bitlis, and Hakkari (Coşkun and Tunçtürk, 2000; Tekinşen, 2004; Şenel et al., 2012). The demand for traditional products has increased due to the popularity of Herby cheese, and the production in industrial environment has enabled it to be recognized internationally (Coşkun and Tunçtürk, 2000; Hayaloglu and Fox, 2008; Tarakci and Akyuz, 2009; Ocak et al., 2015; Tunçtürk and Özökçe, 2015).

Researchers (Coşkun and Tunçtürk, 1998) define Herby cheese as “usually made from sheep's milk (cow's milk is used in the industry), with the addition of some herbs such as wild garlic (Allium spp.), Mint (Lamiaceae), Thyme (Thymus), and some other local aromatic herbs like Mendo (Anthriscus nemorosa), Heliz (Ferula haussknechtii) and Çünk (Ranunculus crateris) and produced by traditional methods. These types of cheeses could be consumed fresh or partly ripened in plastic drums with dry salting or brining.

In the Eastern and Southeastern Anatolia regions of Turkey, the production of Herby cheese varieties has been continuing for centuries. Although the Herby cheese produced in the Province of Siirt and its districts shows similarities to the known (Van) Herby cheese in terms of production steps, it gains its own characteristics thanks to the differences in several steps during production, and proves that it can be considered as a different product under the title of Herby cheese. During the production of Siirt Herby cheese, it is observed that it gains a unique structure and taste by crumbling the curd, adding only one type of herb (Sirik, Allium species), and direct dry salting without adding cacık (Turkish dairy product) (Doğan, 2011).

In this study, proteolysis and lipolysis levels of Siirt Herby cheese were envisaged in addition to other chemical properties. The electrophoretic technique was used to determine the type of milk used in the production stage.

\section{MATERIALS AND METHODS}

\section{Cheese Samples}

Twenty Siirt Herby cheese samples used in the study were randomly selected from cheese stores of the authentic Helvacilar Bazaar of the Province of Siirt in June.

In the different analysis, high purity chemicals of Sigma-Aldrich (Steinheim, Germany) and Merck (Darmstadt, Germany) were used. 


\section{Chemical and Biochemical Analysis}

Dry matter (\%), protein (\%, $\mathrm{N} \times 6.38)$, fat (\%), salt (\%), ash values $(\%)$ and lactic acid titration acidity $(\%)$ were perormed according to the methods described in AOAC (Horwitz, 2000). The pH values were measured by using pH meter (Hanna Inst. 8521).

Water soluble nitrogen (WSN), trichloroacetic acid-soluble nitrogen (TCA-SN), and phosphotungstic acid-soluble nitrogen (PTA-SN) were determined according to the method given by Bütikofer et al. (1993).

The free amino group contents of samples were estimated by the trinitrobenzene sulfonic acid (TNBS) method (Polychroniadou, 1988). The quantity of free amino groups was expressed in glycine equivalents. Blank and calibration tests were carried out to determine the means and standard deviations in the method.

Determination of lipolysis was performed according to the BDI method (Jellema et al., 1991); 10 $\mathrm{g}$ of the crushed cheese sample was transferred to a butyrometer. $20 \mathrm{~mL}$ of BDI reagent was added and the butyrometers were allowed to stand in a boiling water bath for 20 minutes to separate the fat. BDI reagent was prepared by adding $30 \mathrm{~g}$ Triton X-100 and $70 \mathrm{~g}$ sodium tetraphosphate in $1 \mathrm{~L}$ of distilled water. The samples were centrifuged for $1 \mathrm{~min}$ in Gerber centrifuge. Enough aqueous methanol was added to bring the fat into column neck of the bottle and then centrifuged again for $1 \mathrm{~min}$. Then, the fraction of fat was transferred into a $50-\mathrm{mL}$ flask and weighed. A volume of $5 \mathrm{~mL}$ of solvent (4:1, petroleum ether: n-propanol) was added to the flask. Titration was carried out with $0.01 \mathrm{~N}$ tetra n-butyl ammonium hydroxide. The degree of lipolysis was reported as acid degree value (ADV) equation 1.

$$
A D V=\frac{(\mathrm{A}-\mathrm{B}) \times N \times 100}{\text { weight of fat }(\mathrm{g})}
$$

Herein; A is amount of $0.01 \mathrm{~N}$ tetra n-butyl ammonium hydroxide spent for sample $(\mathrm{ml}), \mathrm{B}$ is amount of $0.01 \mathrm{~N}$ tetra n-butyl ammonium hydroxide spent for blank (ml), $\mathrm{N}$ is normality of tetra $\mathrm{n}$ butyl ammonium hydroxide.

\section{Electrophoretic Analysis}

Urea-PAGE electrophoresis of the Siirt Herby cheese was carried out according to the method of Tarakçı et al. (2004). Casein standard was obtained by dissolving sodium caseinate, prepared from sheep, goat and cow milk in urea buffer. The gels were scanned, and the pictures were transferred to the PC.

\section{RESULTS AND DISCUSSION}

\section{Chemical Composition}

The chemical analysis results of Siirt Herby cheese samples are given in Table 1. The average acidity of the cheese samples in lactic acid was found as $0.83 \pm 0.30 \%$. In their study, Doğan (2011) found the average acidity level of $2.44 \pm 0.62 \%$ for Siirt Herby cheese samples collected after maturation . In another study conducted on ripened Siirt Herby cheeses, acidity values were established to range between $0.99 \%$ and $3.00 \%$ (mean $2.28 \pm 0.59 \%$ ) (Doğan, 2012). The results obtained by the previous researchers who used Van Herby cheese showed that the acidity values of the fresh Herby cheese samples were close to that of our results. However, the acidity values of ripened Herby cheese samples were found more higher (Şenel et al., 2012; Tarakçı and Akyuz, 2009; Tarakçi et al., 2004; Tarakçı and Küçüköner, 2006; Tekinşen, 2004; Tunçtürk et al., 2014). The mean pH value of Siirt Herby cheeses was $5.10 \pm 0.39$, and similar values were found in other studies; while in ripened cheese samples, the $\mathrm{pH}$ values were found less than 5 (Tarakçı et al., 2004; Doğan, 2012; Şenel et al., 2012; Hayaloglu and 
Karabulut, 2013a). As a matter of fact, it was reported that the mean $\mathrm{pH}$ value of ripened Siirt Herby cheeses is $4.19 \pm 0.85$ (Doğan, 2011).

Table 1. Some chemical properties of Siirt Herby cheese samples.

\begin{tabular}{cccccccc}
\hline Sample & Acidity $(\% \mathbf{L A})$ & $\mathbf{p H}$ & Dry Matter $(\boldsymbol{\%})$ & Protein (\%) & Fat $(\boldsymbol{\%})$ & Ash $(\boldsymbol{\%})$ & NaCI (\%) \\
\hline 1 & 0.18 & 6.02 & 57.55 & 23.53 & 28.00 & 4.13 & 2.48 \\
2 & 1.13 & 5.23 & 55.33 & 25.21 & 23.00 & 6.51 & 4.74 \\
3 & 0.86 & 4.80 & 54.72 & 21.34 & 24.00 & 6.67 & 6.43 \\
4 & 0.77 & 4.35 & 47.31 & 21.22 & 18.00 & 4.76 & 3.92 \\
5 & 1.35 & 5.07 & 59.29 & 25.20 & 27.00 & 4.99 & 4.97 \\
6 & 1.08 & 5.16 & 47.33 & 19.06 & 18.00 & 7.51 & 5.56 \\
7 & 1.35 & 4.80 & 54.97 & 20.75 & 24.00 & 8.06 & 8.01 \\
8 & 0.77 & 5.12 & 43.56 & 19.54 & 16.00 & 6.03 & 5.03 \\
9 & 0.86 & 5.39 & 46.32 & 20.81 & 20.00 & 4.87 & 4.27 \\
10 & 1.17 & 4.90 & 54.11 & 20.67 & 28.00 & 5.49 & 5.44 \\
11 & 0.41 & 5.22 & 57.52 & 20.78 & 30.00 & 5.36 & 4.92 \\
12 & 1.04 & 5.01 & 54.01 & 22.48 & 25.00 & 5.68 & 5.56 \\
13 & 0.81 & 5.43 & 47.59 & 23.60 & 17.00 & 6.01 & 5.19 \\
14 & 0.77 & 4.77 & 50.08 & 22.46 & 21.00 & 6.34 & 5.67 \\
15 & 0.90 & 5.36 & 52.99 & 20.29 & 21.00 & 7.35 & 6.26 \\
16 & 0.86 & 4.73 & 58.04 & 23.38 & 28.00 & 4.84 & 4.74 \\
17 & 0.68 & 5.40 & 54.32 & 20.31 & 25.00 & 4.95 & 4.86 \\
18 & 0.59 & 4.98 & 53.93 & 20.31 & 27.00 & 4.73 & 4.33 \\
19 & 0.54 & 5.70 & 55.29 & 21.26 & 29.00 & 3.85 & 3.39 \\
20 & 0.50 & 4.58 & 54.33 & 19.90 & 28.00 & 5.47 & 5.14 \\
Min. & 0.18 & 4.35 & 43.56 & 19.06 & 16.00 & 3.85 & 2.48 \\
Max. & 1.35 & 6.02 & 59.29 & 25.21 & 30.00 & 8.06 & 8.01 \\
Mean & 0.83 & 5.10 & 52.93 & 21.61 & 23.85 & 5.68 & 5.05 \\
Value & 0.30 & 0.39 & 4.39 & 1.78 & 4.38 & 1.13 & 1.15 \\
SD $(\sigma)$ & & & & & &
\end{tabular}

Dry matter, salt, and ash values of Herby cheeses in the literature have quite a broad range. This is due to the dry or brine salting practices of cheese samples or lack of a standard salting level. In our study, the mean dry matter value was $52.93 \pm 4.39 \%$. This value is similar to the values obtained by some researchers (Tekinşen, 2004; Doğan, 2011; Doğan, 2012; Hayaloglu and Karabulut, 2013a). The mean ash value of our samples was $5.68 \pm 1.13 \%$, this value was consistent with the values of fresh brined Herby cheese (Sağun et al., 2005). The mean salt value of Siirt Herby cheese samples was 5.07 $\pm 1.29 \%$, and this value was found as $6.93 \pm 1.26 \%$ by Doğan (2011), $5.87 \pm 0.99 \%$ by Doğan (2012), and $5.19 \pm 0.81 \%$ by Tarakçı et al. (2004) and in the fresh samples $6.64 \pm 1.19 \%$, in the ripened cheese samples as $5.52 \pm 1.85 \%$ by Hayaloğlu and Karabulut (2013a).

The mean protein value found in our study was $21.61 \pm 1.78 \%$ which matched the protein value obtained in many other studies (Tarakçı et al., 2004; Tarakci and Akyuz, 2009; Doğan, 2011; Doğan, 2012;). Tarakci et al., (2011) reported that adding herbs at $0.5 \%$ or $1 \%$ levels to Herby cheeses showed different protein values of cheese samples (Tarakçı et al., 2011). The mean fat value $23.85 \pm 4.38 \%$ was similar to that obtained by many studies (Tarakçı et al., 2004; Tarakci and Akyuz, 2009; Doğan, 2011; Doğan, 2012).

\section{Biochemical Composition}

The biochemical analysis results of Siirt Herby cheese samples are given in Table 2. The mean values of WSN, TCA-SN and PTA-SN of the proteolysis level were $9.49 \pm 2.66 \%, 6.33 \pm 2.39 \%$, and $1.48 \pm 0.71 \%$, respectively. In the study carried out by Doğan (Doğan, 2012), WSN and TCA-SN values of ripened Siirt Herby cheese samples were found as $20.66 \pm 4.95 \%$ and $15.72 \pm 1.98 \%$, respectively. The 
values obtained in our study showed WSN and TCA-SN values similar to those reported on Herby cheese (Tarakçı et al., 2004; Tarakçı et al., 2005). In a study conducted on Herby cheese produced by various milk types, the WSN, TCA-SN and PTA-SN values of the cheese samples made from raw milk obtained on the $30^{\text {th }}$ day of storage were consistent with the sample values of our study. Another assay used to determine the level of proteolysis is the proteolysis value (free amino group). This mean value was $61.97 \pm 30.84 \mathrm{mM}$ glycine level. The proteolysis values of the $30^{\text {th }}$ day of storage Herby cheese samples obtained by Tunçtürk et al. (2014) were similar to our results. In another study, the values of the $30^{\text {th }}$ day of storage White cheese (Cinbas and Kilic, 2006) samples were close to our results. The proteolysis values obtained in some White cheese studies are less than the values of our samples (Hesari et al., 2007; Kirkin et al., 2013). The development of proteolysis of Herby cheese samples which were not subjected to a standard maturing procedure differed according to the ambient conditions, and therefore, very different results were found in the proteolysis values of the samples (Table 2).

In order to investigate the lipolytic development of Herby cheese samples, it was determined that our samples showed mean value of $6.00 \pm 2.32 \mathrm{ADV}$. This value is higher than all the values of the reported studies (Coşkun and Tunçtürk, 2000; Tarakçı et al., 2004; Tarakçı et al., 2005; Tarakci and Akyuz, 2009; Tunçtürk et al., 2014). This increase in ADV values of our samples could be the result of the high lipase activity in raw milk samples, the contribution of the esterolytic activity of non-starter lactic acid bacteria (Hayaloğlu and Özer, 2011), the high temperature value of cheese storage permitting the growth of spoilage microorganisms, and the hydrolysis of these microorganisms that liberates lipolytic enzymes.

Table 2. Some biochemical properties of the Siirt Herby cheese samples.

\begin{tabular}{|c|c|c|c|c|c|}
\hline Sample & Lipolysis (ADV) & Proteolysis (mM) & WSN (\%) & TCA-SN (\%) & PTA-SN (\%) \\
\hline 1 & 5.04 & 71.99 & 8.25 & 6.35 & 1.08 \\
\hline 2 & 4.47 & 42.00 & 8.64 & 3.01 & 0.73 \\
\hline 3 & 0.94 & 6.19 & 3.51 & 2.44 & 0.28 \\
\hline 4 & 4.47 & 62.34 & 9.31 & 6.61 & 1.28 \\
\hline 5 & 4.23 & 35.94 & 8.20 & 5.88 & 1.02 \\
\hline 6 & 7.38 & 37.79 & 8.84 & 6.79 & 1.49 \\
\hline 7 & 6.64 & 13.58 & 8.60 & 6.44 & 1.59 \\
\hline 8 & 4.63 & 82.18 & 7.47 & 1.25 & 1.46 \\
\hline 9 & 4.84 & 50.24 & 10.98 & 8.24 & 1.32 \\
\hline 10 & 3.52 & 74.28 & 11.80 & 8.96 & 1.80 \\
\hline 11 & 6.24 & 44.01 & 10.29 & 6.01 & 1.56 \\
\hline 12 & 4.75 & 70.04 & 9.91 & 6.63 & 1.43 \\
\hline 13 & 7.01 & 81.90 & 9.04 & 5.68 & 2.34 \\
\hline 14 & 7.14 & 42.33 & 10.08 & 6.54 & 1.17 \\
\hline 15 & 7.69 & 59.99 & 5.88 & 4.56 & 1.03 \\
\hline 16 & 6.48 & 58.81 & 8.42 & 6.80 & 1.06 \\
\hline 17 & 8.47 & 123.03 & 10.24 & 8.68 & 1.85 \\
\hline 18 & 12.46 & 131.61 & 16.29 & 12.20 & 3.83 \\
\hline 19 & 7.02 & 79.66 & 13.82 & 6.09 & 1.80 \\
\hline 20 & 6.59 & 71.42 & 10.14 & 7.46 & 1.44 \\
\hline Min. & 0.94 & 6.19 & 3.51 & 1.25 & 0.28 \\
\hline Max. & 12.46 & 131.61 & 16.29 & 12.2 & 3.83 \\
\hline Mean Value & 6.00 & 61.97 & 9.49 & 6.33 & 1.48 \\
\hline $\operatorname{SD}(\sigma)$ & 2.32 & 30.84 & 2.66 & 2.39 & 0.71 \\
\hline
\end{tabular}

\section{Electrophoresis}

As a result of electrophoretic analyses (Figure 1), the sheep's milk was more favourable in Siirt Herby cheese production than other milk types. In addition to sheep's milk, it was observed that cow's 
and goat's milk or both were mixed with sheep's milk and used in the Herby cheese production. Tarakç1 et al. (2004) reported that sheep's and cow's milk mixture is preferred in Van Herby cheese production. In the same study, only cow's milk was used for certain cheeses production. As a result of electrophoretic analysis in which proteolytic activity can be observed, almost all the caseins $\alpha_{\mathrm{s}} 1$ were broken down, and that this was also seen in the free amino group values of the same samples (Figure 1 and Table 2; samples 17 and 18).

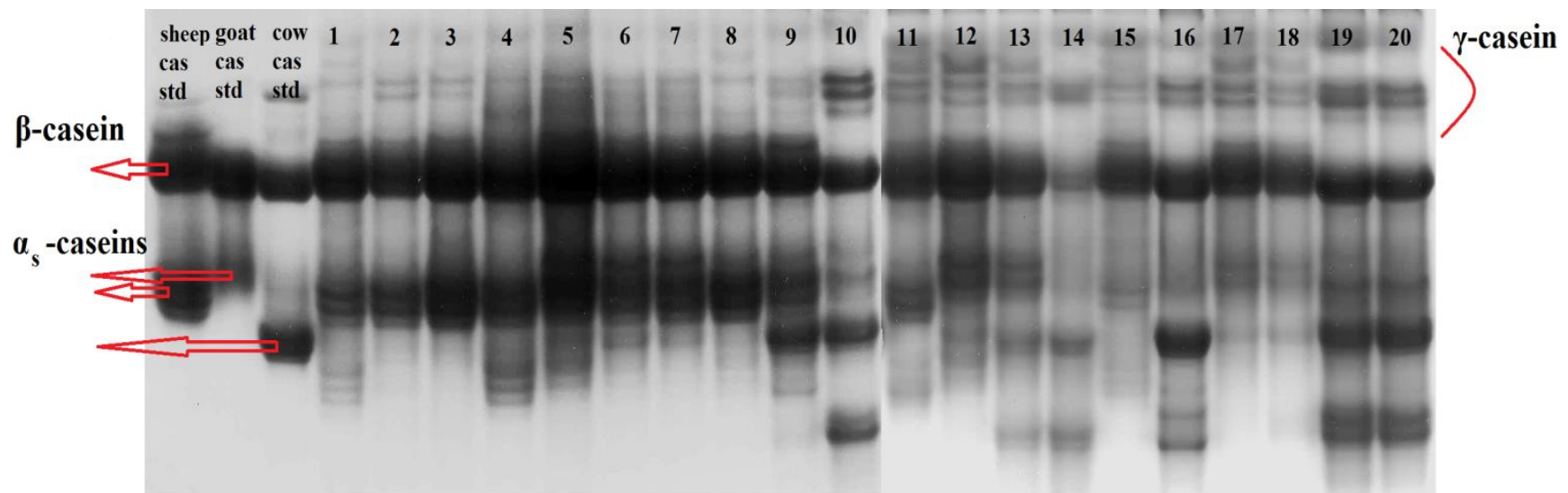

Figure 1. Ure-PAGE Electrophoretograms of Siirt Herby cheese samples. (sheep cas std: sheep casein standard; goat cas std: goat casein standard; cow cas std: cow casein standard).

\section{CONCLUSION}

It is obvious that Siirt Herby cheese that is widely produced in different regions of Turkey needs more investigation studies to determine all of its characteristics. The high activity of proteolysis and lipolysis of these cheese samples could be related to the absence of a ripening stage. Another reason of this high activity of proteolysis and lipolysis could be the high temperatures of the storage places of cheeses. Another study could be performed to evaluate the effect of collection time of milk on the Herby cheese quality attributes.

\section{REFERENCES}

Bütikofer U, Rüegg M, Ardö Y, 1993. Determination of nitrogen fractions in cheese: Evaluation of a collaborative study. LWT-Food Science and Technology. 26, 271-275.

Cinbas T, Kilic M, 2006. Proteolysis and lipolysis in White cheeses manufactured by two different production methods. International Journal of Food Science and Technology. 41, 530-537.

Coşkun H, Tunçtürk Y, 2000. The effect of Allium sp. on the extension of lipolysis and proteolysis in Van Herby cheese during maturation. Food/Nahrung 44, 52-55.

Coşkun H, Tunçtürk Y, 1998. Van Otlu peyniri (Van Herby cheese). Geleneksel Süt Ürünleri. V. Süt ve Süt Ürünleri Sempozyumu 21-22.

Doğan C, 2011. Traditional Production Process and Composition of Siirt Herby Cheese. Msc Thesis, Kahramanmaraş Sütçü İmam Univ, Kahramanmaraş-Türkiye.

Doğan N, 2012. Determination of Some Properties of "Siirt Otlu Cheese" That Produced in Siirt Province. Msc Thesis, Harran Univ, Şanlıurfa-Türkiye.

Hayaloglu AA, Fox PF, 2008. Cheeses of Turkey: 3. Varieties containing herbs or spices. Dairy Science and Technology. 88, 245-256.

Hayaloglu AA, Karabulut I, 2013a. SPME/GC-MS characterization and comparison of volatiles of eleven varieties of Turkish cheeses. International Journal of Food Properties. 16, 1630-1653. 
Hayaloglu AA, Karabulut I, 2013b. Primary and secondary proteolysis in eleven Turkish cheese varieties. International Journal of Food Properties. 16, 1663-1675.

Hayaloğlu AA, Özer B, 2011. Peynir Biliminin Temelleri (Basics of Cheese Science). SİDAŞ Medya Ltd 643.

Hesari J, Ehsani MR, Mosavi MAE, Mcsweeney PLH, 2007. Proteolysis in ultra-filtered and conventional Iranian White cheese during ripening. International Journal of Dairy Technology. 60, 211-220.

Horwitz W, 2000. Official Methods of Analysis of AOAC International, 17th Edition. Association of Official Analytical Chemists, Gaithersburg, Md.

Jellema A, Anderson M, Heeschen W, Kuzdal-Savoie S, Needs EC, Suhren G, Van Reusel A, 1991. Determination of free fatty acids in milk and milk products. Bulletin of the International Dairy Federation no. 265.

Kavaz A, Bakirci I, Kaban G, 2013. Changes of volatile compounds of Herby cheese during the storage period. Kafkas Universitesi Veteriner Fakültesi Dergisi. 19: 535-540..

Kirkin C, Gunes G, Kilic-Akyilmaz M, 2013. Preservation of precut White cheese by modified atmosphere packaging. International Journal of Dairy Technology. 66, 576-586.

Ocak E, Javidipour I, Tuncturk Y, 2015. Volatile compounds of Van Herby cheeses produced with raw and pasteurized milks from different species. Journal of Food Science and Technology. 52, 4315-4323.

Polychroniadou A, 1988. A simple procedure using trinitrobenzenesulphonic acid for monitoring proteolysis in cheese. Journal of Dairy Research. 55, 585-596.

Sağun E, Tarakçı Z, Sancak H, Durmaz H, 2005. Salamura Otlu peynirde olgunlaşma süresince mineral madde değişimi (Changes of mineral matter during ripening of pickled Herby cheese). Yüzüncü Yıl Üniversitesi Veteriner Fakültesi Dergisi. 16, 21-25.

Şenel E, Yildiz F, Yetişemiyen A, 2012. Evaluation of the biogenic amine content and some chemical and microbiological properties of Urfa and Van Herby cheeses. Kafkas Universitesi Veteriner Fakültesi Dergisi. 18 (4), 537-544.

Tarakçı Z, Akyuz N, 2009. Effects of packaging materials and filling methods on selected characteristics of Otlu (Herby) cheese. International Journal of Food Properties. 12, 496-511.

Tarakçi Z, Coşkun H, Tunçtürk Y, 2004. Some properties of fresh and ripened Herby cheese, a traditional variety produced in Turkey. Food Technology and Biotechnology. 42, 47-50.

Tarakci Z, Temiz H, 2009. A review of the chemical, biochemical and antimicrobial aspects of Turkish Otlu (Herby) cheese. International Journal of Dairy Technology. 62, 354-360.

Tarakci Z, Temiz H, Aykut U, Turhan S, 2011. Influence of wild garlic on color, free fatty acids, and chemical and sensory properties of Herby pickled cheese. Internatioanl Journal of Food Properties. 14, 287-299.

Tarakçı Z, Durmaz H, Sağun E, 2005. Siyabonun (Ferula sp.) otlu peynirin olgunlaşması üzerine etkisi (The effect of Siyabo (Ferula sp.) on ripening of Herby cheese). Yüzüncü Yı1 Üniversitesi Tarım Bilimleri Dergisi. 15, 53-56.

Tarakçı Z, Küçüköner E, 2006. Farklı yağ oranına sahip sütten üretilen Van Otlu peynirlerinde olgunlaşma süresinde meydana gelen değişiklikler (Changes in the ripening time of Van Herby cheese produced from milk with different fat ratios). Yüzüncü Y1l Üniversitesi Tarım Bilimleri Dergisi. 16, 19-24.

Tekinşen KK, 2004. Hakkari ve çevresinde üretilen Otlu peynirlerin mikrobiyolojik ve kimyasal kalitesi (Microbiological and chemical quality of Herby cheese produced in and around Hakkari). Eurasian Journal of Veterinary Sciences. 20 (2),070-085.

Tunçtürk M, Eryiğit T, Kaya AR, 2017. Nutritional properties, minerals, and selected heavy metal contents in Herby cheese plants of Lamiaceae. Applied Biological Chemistry. 60, 41-47.

Tunçtürk M, Özgökçe F, 2015. Chemical composition of some Apiaceae plants commonly used in Herby cheese in Eastern Anatolia. Turkish Journal of Agriculture and Forestry. 39, 55-62.

Tunçtürk Y, Ocak E, Köse Ș, 2014. Changes in chemical and physical properties and proteolysis of Van Herby (Otlu) cheese during ripening. GIDA The Journal of Food. 39, 163-170. 